M. Colin - M.-P. Dorthu - F. Duby - C. Remacle

M. Dinant - M.-R. Wolwertz

C. Duyckaerts - F. Sluse - R. F. Matagne

\title{
Mutations affecting the mitochondrial genes encoding the cytochrome oxidase subunit I and apocytochrome $b$ of Chlamydomonas reinhardtif
}

Received: 29 March 1995/Accepted: 23 June 1995

\begin{abstract}
Mitochondrial mutants of the green alga Chlamydomonas reinhardtii that are inactivated in the cytochrome pathway of respiration have previously been isolated. Despite the fact that the alternative oxidase pathway is still active the mutants have lost the capacity to grow heterotrophically (dark + acetate) and display reduced growth under mixotrophic conditions (light + acetate). In crosses between wild-type and mutant cells, the meiotic progeny only inherit the character transmitted by the $m t^{-}$parent, which indicates that the mutations are located in the $15.8 \mathrm{~kb}$ linear mitochondrial genome. Two new mutants (dum18 and dum-19) have now been isolated and characterized genetically, biochemically and at the molecular level. In addition, two previously isolated mutants (dum-11 and dum-15) were characterized in more detail. dum-11 contains two types of deleted mitochondrial DNA molecules: $15.1 \mathrm{~kb}$ monomers lacking the subterminal part of the genome, downstream of codon 147 of the apocytochrome $b(\mathrm{COB})$ gene, and dimers resulting from head-to-head fusion of asymmetrically deleted monomers (15.1 and 9.5 kb DNA molecules, respective1y). As in the wild type, the three other mutants contain only $15.8 \mathrm{~kb}$ mitochondrial DNA molecules. dum-15 is mutated at codon 140 of the COB gene, a serine (TCT) being changed into a tyrosine (TAC). dum- 18 and dum19 both inactivate cytochrome $c$ oxidase, as a result of frameshift mutations (addition or deletion of $1 \mathrm{bp}$ ) at codons 145 and 152, respectively, of the COXI gene
\end{abstract}

\section{Communicated by R. Herrmann}

M. Colin · M.-P. Dorthu · F. Duby - C. Remacle - M. Dinant M.-R. Wolwertz $\cdot$ R. F. Matagne $(\bowtie)$

Génétique des microorganismes, Departement de Botanique, B22, Université de Liège, Sart Tilman, B-4000 Liège, Belgium

C. Duyckaerts · F. Sluse

Bioénergétique, Centre Interdisciplinaire de Biochimie normale et pathologique de l'Oxygène, B6, Université de Liège, Sart Tilman, B-4000 Liège, Belgium encoding subunit I of cytochrome $c$ oxidase. In a to1 of ten respiratory deficient mitochondrial mutar characterized thus far, only mutations located in CC or COX1 have been isolated. The possibility that $t$ inactivation of the other mitochondrial genes is leth for the cells is discussed.

Key words Chlamydomonas - Mitochondrial genetic Cytochrome $c$ oxidase $\cdot$ Apocytochrome $b$

\section{Introduction}

The mitochondrial genome of Chlamydomonas reinhe dtii is a linear DNA molecule of $15.8 \mathrm{~kb}$ present about 50 copies per cell (for a review, see Harris 198 The complete mitochondrial DNA sequence has be determined and 13 genes have been identified: subus 1 of cytochrome $c$ oxidase (COX1), apocytochror $b$ (COB), subunits $1,2,4,5$ and 6 of the NAD dehydrogenase (ND 1, 2, 4, 5 and 6), a reverse transcri tase-like protein (RTL), and three tRNA (Gln, Met a! Trp), and the large (L1-L8) and small (S1-S4) rRN segments (Fig. 1) (for recent data, see Michaelis et 1990; Ma et al. 1990; Vahrenholz et al. 1993). In cross the meiotic products most often inherit the mitocho drial DNA from the $m t^{-}$parent (uniparental minus UP $^{-}$inheritance) (Boynton et al. 1987; Matagne et 1989; Beckers et al. 1991) whereas the chloroplast DN is preferentially transmitted from the $m t^{+}$parent.

Mitochondrial mutations have recently been charc terized in C. reinhardtii. Bennoun et al. (1991, 19s isolated mutants resistant to myxothiazol and mucid two antibiotics acting on the cytochrome $b c_{l}$ compl All mutants have point mutations in the COB ges Mutations that inactivate mitochondrial genes ha also been identified (Matagne et al. 1989; Dorthu et 1992; Randolph-Anderson et al. 1993). These $\mathrm{dk}^{-} \mathrm{m}$ tants are unable to grow under heterotrophic con tions (dark + acetate), owing to loss of the cytochrol 


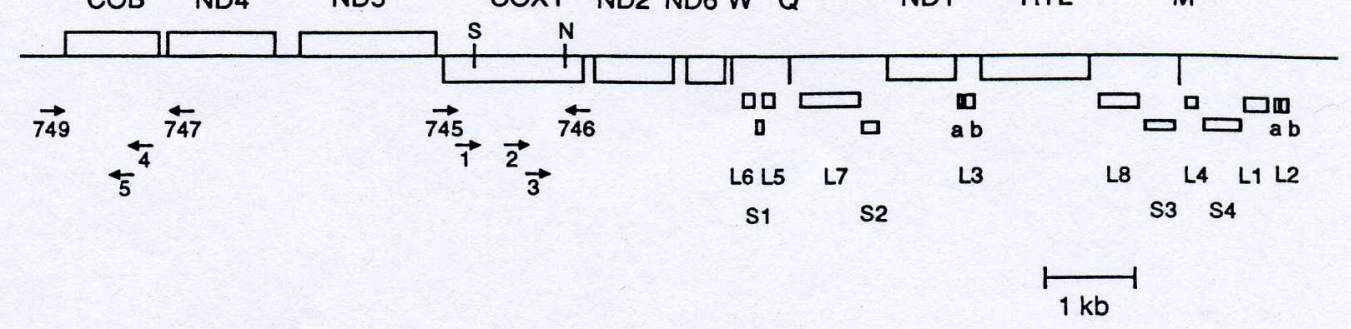

pathway of respiration. Most of them have a deletion of $0.7-1.6 \mathrm{~kb}$ extending from the left end of the mitochondrial genome through most of the COB gene. In contrast to wild-type cells in which only $15.8 \mathrm{~kb}$ molecules are observed, the mutant cells contain a mixture of deleted monomers and dimers. The dimers most often result from fusion of two monomers at their deleted ends. A few $\mathrm{dk}^{-}$mutants have no detectable deletion and their genome is of monomer length. One of them (dum-15) is defective in complex III and thus presumably mutated in the COB gene.

We here describe two new mutations (dum-18 and dum-19) that are located in the COX1 gene. Both of them correspond to frameshift mutations that cause the inactivation of the cytochrome $c$ oxidase complex. Two previously isolated mutants (dum-11 and dum-15) are also characterized in more detail.

\section{Materials and methods}

Strains and culture conditions

The wild-type and mutant strains are derived from strain 137c. The cells were grown on agar plates (15 g/1 Gibco agar) or in liquid medium, under cool white fluorescent light $\left(45 \mu \mathrm{E} / \mathrm{m}^{2}\right.$ per second) or in the dark, at $25^{\circ} \mathrm{C}$. Two culture media were used: TRIS-minimal phosphate (TMP) and TRIS-acetate phosphate (TAP) medium (Gorman and Levine 1965). Doubling times of cells grown in liquid cultures were determined from counts performed with a ZF Coulter counter.

Mutagenesis, and genetic and biochemical analyses

The $d k^{-}$mutants were induced by growing $\mathrm{mt}^{-}$wild-type cells in TAP liquid medium containing acriflavine $(6-8 \mu \mathrm{g} / \mathrm{ml})$. The transmission pattern of the mutations was determined by random analysis of meiotic products. The activity of the cytochrome pathway of respiration was estimated by an in vivo staining test using $2,3,5$ triphenyltetrazolium chloride (TTC) as an electron acceptor. The enzyme activities of the antimycin-sensitive succinate cytochrome $c$ oxidoreductase (complexes II + III) and of the cytochrome $c$ oxidase (complex IV) were measured from whole cell homogenates. These various procedures have been described by Dorthu et al. (1992).

Molecular and sequencing analyses

The search for possible deletions $(0.2 \mathrm{~kb}$ or more) in the mutant strains was performed by DNA hybridization with homologous
Fig. 1 Genetic map of the linear $15.8 \mathrm{~kb}$ mitochondrial genome Chlamydomonas reinhardtii. The two large arrows indicate directi of transcription. Genes are represented by rectangles: $\mathrm{CC}$ apocytochrome $b$ (1143 bp); ND 1, 2, 4, 5 and 6 , subunits of NAI dehydrogenase; COX1, subunit I of cytochrome $c$ oxidase (1515 I RTL, reverse transcriptase-like gene; $W, Q$ and $M, t-R N A s$ tryptophan, glutamine and methionine; $\mathrm{S} 1-4$, fragments of the sn ribosomal RNA; L1-8, fragments of the large ribosomal RNA references, see Vahrenholz et al. 1993). The small arrows indicate positions of the primers used for polymerase chain reaction ( $P($ amplification or for DNA sequencing (see text). $\mathrm{N}$ and $\mathrm{S}$ corresp to the positions of the NheI and Sst I restriction sites in COX1

probes on Southern blots as previously described (Dorthu et 1992).

For cloning, wild-type and mutant DNA fragments containing COX 1 or the COB gene were amplified by the polymerase ch reaction (PCR) using $1 \mu \mathrm{g}$ of total DNA and two of the follow oligonucleotides: 745 (5'-GGAATTCGAACTAAAGAAGAAG ATTCTA), which primes at the beginning of the ND5 gene : within the region between ND5 and COX1; 746 (5'-CGGGA ${ }^{\prime}$ CTATGACACGCGTAACAGCTC), which primes within region between ND2 and COX1; 747 (5'-CGGGATCCGGTGC TATGGCTAGGTAT), which primes from the end of ND4, and (5'-CGGAATTCCGCGTACCGTAAGTGTAAA), which pri within the region downstream of COB (Fig. 1). Each primer cont: a restriction site ( $E c o \mathrm{RI}$ or $\mathrm{BamHI})$ for subsequent subcloning.

In each case,the reaction mixture was subjected to 35 cycle $1 \mathrm{~min}$ at $94^{\circ} \mathrm{C}, 2 \mathrm{~min}$ at $55^{\circ} \mathrm{C}$ and $1 \mathrm{~min}$ at $70^{\circ} \mathrm{C}$ with a $\mathrm{f}$ extension step of $7 \mathrm{~min}$ at $70^{\circ} \mathrm{C}$, using a Techne PHC-3 thermor ler. The amplified fragments digested with EcoRI and BamHI v cloned into the pUC19 vector. In addition, NheI and SstI subclc were constructed for sequencing the COX 1 gene. Several clones $f_{1}$ independent amplification reactions were sequenced to elimi possible errors due to misincorporation by the polymerase $\mathrm{du}$ the amplification reaction.

Universal and reverse primers, three primers internal to the $\mathrm{CC}$ gene $(1,2,3$; positions $172-189,676-693,871-888$, respectiv and two primers internal to the COB gene $(4,5$; positions 84 284-301, respectively) were used for sequence analysis (Fig. 1). quencing was performed by the dideoxy chain termination met of Sanger et al. (1977) using $\left[\%_{-}^{35} \mathrm{~S}\right] \mathrm{dATP}$ purchased from $\mathrm{Ar}$ sham, and T7 DNA polymerase (Pharmacia LKB Biotechnolo

\section{Results}

Two mutants unable to grow under heterotrop conditions $\left(\mathrm{dk}^{-}\right.$phenotype) were induced after a flavine treatment of the $m t^{-}$wild strain. In cros with $\mathrm{mt}^{+}$wild-type gametes, the meiotic prog inherited the $\mathrm{dk}^{-}$character. In both crosses, $\mathrm{a} \mathrm{dk}^{-} r$ 
Table 1 Meiotic segregation of the $\mathrm{dk}^{+}$and $\mathrm{dk}^{-}$phenotypes in reciprocal crosses between wild-type $\left(\mathrm{dk}^{+}\right)$and mutant $\left(\mathrm{dk}^{-}\right)$cells

\begin{tabular}{llrl}
\hline $\begin{array}{l}\text { Mutant } \\
\text { no. }\end{array}$ & $\begin{array}{l}\text { Phenotype of the } \\
m t^{-} \text {parent }\end{array}$ & Segregation & $\begin{array}{l}\text { Name of } \\
\text { the mutant }\end{array}$ \\
\hline 1 & $\begin{array}{l}\text { Mutant } \\
\text { Wild }\end{array}$ & $0 \mathrm{dk}^{+}: 30 \mathrm{dk}^{-}$ & dum-18 \\
& $\begin{array}{l}\text { Mutant } \\
2\end{array}$ & $0 \mathrm{dk}^{+}: 42 \mathrm{dk}^{-}$ & dum-19 \\
& Wild & $42 \mathrm{dk}^{+}: 0 \mathrm{dk}^{-}$ & \\
\hline
\end{tabular}
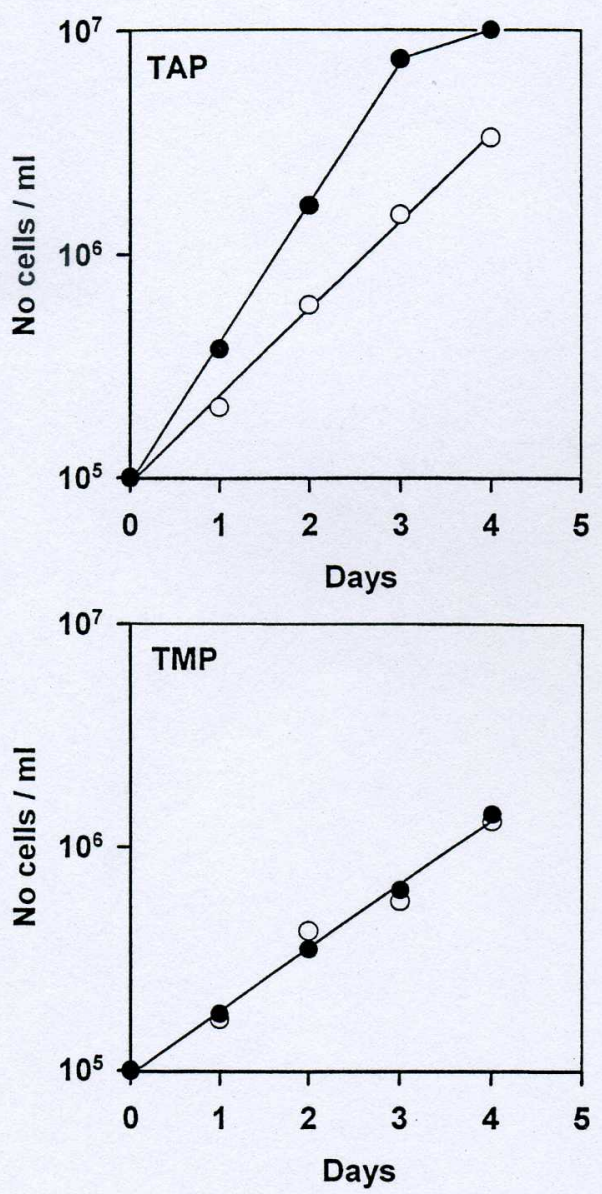

Fig. 2 Growth curves of wild-type (closed symbols) and dum-19 (open symbols) cells cultivated in liquid medium under mixotrophic (TAP) or photoautotrophic (TMP) conditions

clone was selected and crossed to the wild-type $m t^{-}$. In this case, all the progeny inherited the $\mathrm{dk}^{+}$phenotype (Table 1). This $\mathrm{UP}^{-}$transmission observed in the two reciprocal crosses is indicative of a mutation in the mitochondrial genome. The mutants were named dum18 and dum-19 (dark ${ }^{-} u$ niparental minus inheritance).

The two mutants were phenotypically identical to the deletion mutants previously described (Dorthu et al. 1992). They were characterized by their inability to grow under heterotrophic conditions and their slower growth under mixotrophic conditions as compared with the wild type. Under photoautotrophic
Table 2 Activities of succinate-cytochrome $c$ oxidoreductase and cytochrome $c$ oxidase (nanomoles reduced or oxidized cytochrome $c$ per minute per $10^{7}$ cells) in wild-type and mutant strains (results of 2-3 independent experiments)

\begin{tabular}{llc}
\hline Strain & $\begin{array}{l}\text { Succinate-cytochrome } c \\
\text { oxidoreductase }( \pm \mathrm{SD})\end{array}$ & $\begin{array}{c}\text { Cytochrome } c \\
\text { oxidase }( \pm \mathrm{SD})\end{array}$ \\
\hline Wild type & $1.1( \pm 0.3)$ & $55.0( \pm 22.0)$ \\
dum-18 & $1.1( \pm 0.4)$ & $0.5( \pm 0.4)$ \\
dum-19 & $1.0( \pm 0.4)$ & $0.4( \pm 0.4)$ \\
\hline
\end{tabular}

conditions, the growth of mutant cells was not significantly reduced. The data in Fig. 2 on mutant dum-19 moreover show that the presence of acetate in the culture medium slightly improves the growth of the mutant in the light, which indicates that dum-19 can still utilize exogenous acetate as an energy source.

The activity of the cytochrome pathway of respiration was detected by an in vivo staining test using TTC as an electron acceptor (Dorthu et al. 1992). Wild-type and dum-15 mutant cells were used as positive and negative controls. No reaction was obtained with dum-15, dum-18 and dum-19 whereas a brown-red coloration was observed with the wild-type colonies. Respiration measurements moreover showed that the cyanide-resistant pathway of respiration (alternative oxidase) was not altered in the mutants (data not shown).

Measurements of the activities of the respiratory complexes II + III and IV demonstrated the loss of cytochrome $c$ oxidase activity in dum- 18 and dum-19 (Table 2). As subunit 1 is the only component of cytochrome $c$ oxidase encoded by the mitochondrial genome (see Fig. 1), we can deduce that dum-18 and dum-19 mutations involve the COX1 gene.

In order to detect possible deletions in the mitochondrial genome of dum-18 and dum-19, total DNA was extracted and cleaved with SstI to generate two fragments of 10.4 and $5.4 \mathrm{~kb}$ from the mitochondrial DNA (Dorthu et al. 1992). After electrophoresis, the DNA fragments were transferred onto a nylon membrane and detected by hybridization with a specific probe. The restriction patterns were identical for the wild-type and mutant strains (data not shown), indicating that no detectable deletion was present in dum-18 and dum-19.

The COX1 genes of the two mutants were then sequenced and compared with that of the wild type. The 505-amino acid wild-type COX1 sequence was identical to that described by Kück and Neuhaus (1986) and Boer and Gray (1986). In dum-18, addition of a $T$ at codon 145 induced a frameshift downstream of that position. In dum-19, deletion of a $\mathrm{T}$ was found at codon 152, changing aTTG (Leu) into a TGA (stop) codon (Fig. 3). Less than one-third of the correct polypeptide sequence is thus present in either mutant strain.

The dum-11 mutant has previously been partially characterized (Dorthu et al. 1992). This strain possesses 


\begin{tabular}{|c|c|c|c|c|c|c|c|c|c|c|c|}
\hline \multirow[t]{3}{*}{$\cos 1$} & Wild-type & $\begin{array}{c}\text { ATT } \\
\text { lle }\end{array}$ & $\begin{array}{l}\text { TTG } \\
\text { Leu }\end{array}$ & $\begin{array}{l}\text { AGC } \\
\text { Ser }\end{array}$ & $\begin{array}{l}\text { TTG } \\
\text { Leu }\end{array}$ & $\begin{array}{c}\text { CAC } \\
\text { His }\end{array}$ & $\begin{array}{l}\text { TTG } \\
\text { Leu }\end{array}$ & $\begin{array}{l}\text { AAC } \\
\text { Asn }\end{array}$ & $\begin{array}{l}\text { GGT } \\
\text { Gly }\end{array}$ & $\begin{array}{l}\text { TTG } \\
\text { Leu }\end{array}$ & $\begin{array}{c}\text { AGC } \\
\text { Ser }\end{array}$ \\
\hline & dum-18 & $\underset{\mathrm{Hle}}{\mathrm{A} T \mathrm{~T}}$ & $\begin{array}{l}\pi^{+} \\
\text {Phe }\end{array}$ & $\begin{array}{l}\text { GAG } \\
\text { Glu }\end{array}$ & $\begin{array}{l}\text { CTT } \\
\text { Leu }\end{array}$ & $\begin{array}{l}\text { GCA } \\
\text { Ala }\end{array}$ & $\begin{array}{l}\text { CTT } \\
\text { Leu }\end{array}$ & $\begin{array}{l}\text { GAA } \\
\text { Glu }\end{array}$ & $\begin{array}{l}\text { CGG } \\
\text { Arg }\end{array}$ & $\begin{array}{l}\text { TIT } \\
\text { Phe }\end{array}$ & $\begin{array}{l}\text { GAC } \\
\text { Glu }\end{array}$ \\
\hline & dum-19 & $\underset{\mathrm{He}}{\mathrm{ATT}}$ & $\begin{array}{l}\text { TTG } \\
\text { Leu }\end{array}$ & $\begin{array}{l}\text { AGC } \\
\text { Ser }\end{array}$ & $\begin{array}{l}\text { TTG } \\
\text { Leu }\end{array}$ & $\begin{array}{l}\text { CAC } \\
\text { His }\end{array}$ & $\begin{array}{l}\text { TTG } \\
\text { Leu }\end{array}$ & $\begin{array}{l}\text { AAC } \\
\text { Asa }\end{array}$ & $\begin{array}{c}\text { GGT } \\
\text { Gly }\end{array}$ & $\begin{array}{l}\text { TGA } \\
\text { Stop } \\
\end{array}$ & \\
\hline \multirow[t]{2}{*}{$\mathrm{COB}$} & Wild-type & $\begin{array}{l}\text { GGC } \\
\text { Gly }\end{array}$ & $\begin{array}{l}\text { CAA } \\
\text { Gln }\end{array}$ & $\begin{array}{l}\text { ATG } \\
\text { Met }\end{array}$ & $\begin{array}{l}140 \\
\text { TCT } \\
\text { Ser }\end{array}$ & $\begin{array}{l}\text { TTC } \\
\text { Phe }\end{array}$ & $\begin{array}{c}\text { TGG } \\
\text { Try }\end{array}$ & $\begin{array}{l}\text { GGT } \\
\text { Gly }\end{array}$ & $\begin{array}{l}\text { GCT } \\
\text { Ala }\end{array}$ & $\begin{array}{r}145 \\
\text { ACC } \\
\text { Thr }\end{array}$ & \\
\hline & dum-15 & $\begin{array}{c}\text { GGC } \\
\text { Gly }\end{array}$ & $\begin{array}{l}\text { CAA } \\
\text { Glu }\end{array}$ & $\begin{array}{l}\text { ATG } \\
\text { Met }\end{array}$ & $\begin{array}{l}\text { TAC } \\
\text { Iyr }\end{array}$ & $\begin{array}{l}\text { TTC } \\
\text { Phe }\end{array}$ & $\begin{array}{c}\text { TGG } \\
\text { Try }\end{array}$ & $\begin{array}{c}\text { GGT } \\
\text { Gly }\end{array}$ & $\begin{array}{c}\text { GCT } \\
\text { Ala }\end{array}$ & $\begin{array}{l}\text { ACC } \\
\text { Thr }\end{array}$ & \\
\hline
\end{tabular}

a $0.7 \mathrm{~kb}$ deletion in the mitochondrial DNA, located in the COB gene downstream of the $\mathrm{NcoI}$ restriction site. This site is $402 \mathrm{bp}$ from the $5^{\prime}$ end of the coding gene sequence. The $\mathrm{HpaI}$ site located $634 \mathrm{bp}$ downstream of this $5^{\prime}$ end is also missing in the mutant. As the COB gene consists of a $1143 \mathrm{bp}$ open reading frame (Ma et al. 1990; Michaelis et al. 1990) and is followed by a terminal linear sequence of $547 \mathrm{bp}$ (Vahrenholz et al. 1993), the deletion must include the second half of the gene sequence and perhaps a small part of the telomeric end. The mutant cells also contain dimeric mitochondrial DNA molecules, resulting from the fusion of two unequally deleted monomers at their deleted ends: a monomer carrying the $0.7 \mathrm{~kb}$ deletion and a monomer of about $9.5 \mathrm{~kb}$, retaining the end of COX1 and the right part of the genome (Dorthu et al. 1992 and Fig. 1).

The junction between the two monomers in the dimer was identified by sequence analysis after PCR amplification using primers 746 and 747 . The data (Fig. 4) show that the large monomer has retained the first $443 \mathrm{bp}$ of $\mathrm{COB}$ whereas the small monomer has conserved the right part of the genome, downstream of bp 1192 in COX1.

Since dum-15 does not contain any detectable deletion and has a defect in complex III (Dorthu et al. 1992), we concluded that dum-15 is most probably mutated in the COB gene. On the other hand, recombination studies performed on diploid clones showed that dum-15 and dum-11 can recombine (Remacle et al. 1995), which indicates that the dum-15 mutation must be located within the DNA segment retained in dum-11, i.e. the first $443 \mathrm{bp}$ of the COB gene. The COB genes of $d u m-15$ and the wild type have been sequenced. A $2 \mathrm{bp}$ substitution was found at codon 140, changing TCT (Ser) into TAC (Tyr) (Fig. 3). The 381 amino acid wild-type sequence was identical to that described by Michaelis et al. (1990), except at codon 280 where a GCC (Ala) was found instead of GCT (Ala; conserva-

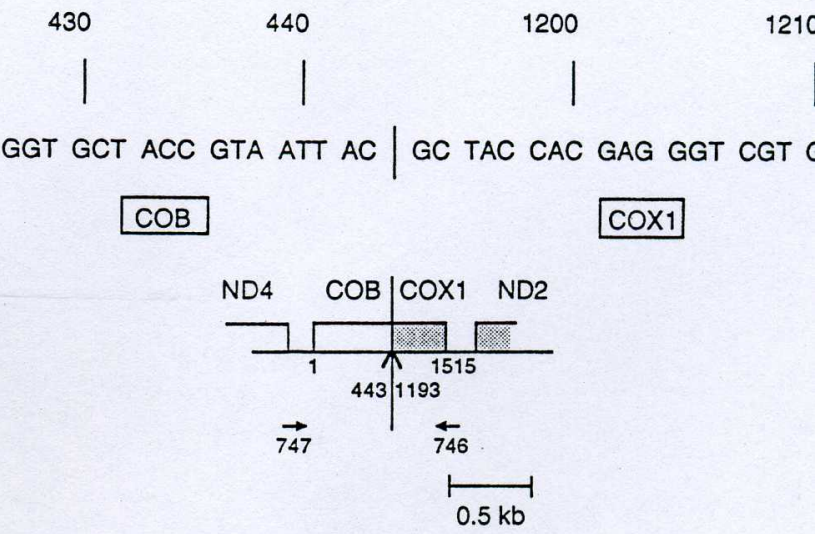

Fig. 4 Junction sequence between the first $443 \mathrm{bp}$ of $\mathrm{COB}$ and terminal part of COX1 downstream of bp 1192 in the dim molecules of dum-11. The numbering of the base pairs starts at A of the ATG initiation codon of each gene. The lower part of figure indicates the positions of the primers (746 and 747) user amplify the sequence by PCR (see text)

tive substitution). In the strain analyzed by Bennc et al. (1991), codon 188 corresponds to CTC (L whereas in the strains used by Michaelis et al. (19 and by us, it corresponds to TTC (Phe).

\section{Discussion}

Two new mitochondrial mutants, $d u m-18$ and dumunable to grow under heterotrophic conditions, totally defective in cytochrome $c$ oxidase. In both ca the null phenotype results from a frameshift mutat in the gene encoding subunit I of the cytochrc $c$ oxidase complex. Note that in each mutant, the ac tion or deletion occurs in a segment where three or $f$ successive AT base pairs are present. The two muta were isolated after treatment with acriflavine, 
mutagen known to induce frameshift mutations preferentially.

dum-15 has an inactive ubiquinol-cytochrome $c$ oxidoreductase as a result of a change at codon 140 (a serine being converted into a tyrosine). The $\mathrm{COB}$ gene of $C$. reinhardtii encodes a polypeptide of 381 amino acid residues. The protein shows a hydropathy profile similar to that of apocytochrome $b$ from other organisms (Michaelis et al. 1990; Colleaux et al. 1990). This profile fits the eight-transmembrane-helix model proposed by Brasseur (1988) and di Rago and Colson (1988). Codon 140 is located in the amino acid sequence GQMSFWGAT (137-145), which is highly conserved in many bacterial and eukaryotic apocytochrome $b$ proteins (di Rago et al. 1989). According to the eight-transmembrane-helix model, this segment is part of the protruding loop between helices 3 and 4 . It would be involved in electron transfer at the ubiquinone redox site Qo at the outer (positive) side of the mitochondrial inner membrane (di Rago et al. 1989). The amino acid residue mutated in dum- 15 is also located in a segment of the cytochrome $b$ polypeptide that is most probably involved in the binding of myxothiazol: in Chlamydomonas, yeast, mouse and Rhodobacter capsulatus, substituted residues that confer resistance to this respiratory inhibitor are found at positions 129, 132, 137, 143 and 147 (see Fig. 2 in Bennoun et al. 1992).

Thus far, ten respiratory defective mitochondrial mutants unable to grow heterotrophically have been characterized in $C$. reinhardtii, including the mutants described in the present article (Matagne et al. 1989; Dorthu et al. 1992; Randolph-Anderson et al. 1993). All of them are mutated in COB or in COX1. These mutants are unable to oxidize the reduced products from glycolysis, the pentose phosphate pathway and the Krebs cycle by the cytochrome pathway since they are defective in complex III (ubiquinol cytochrome $c$ oxidoreductase) or complex IV (cytochrome $c$ oxidase). However, the electrons donated to the ubiquinone-ubiquinol pool can still be transferred to oxygen via the alternative oxidase. In contrast to complexes III and IV, the alternative oxidase is considered as non-phosphorylating (Laties 1982), with the only possibility for ATP production via electron transport mediated by the alternative pathway being through complex I (NADH dehydrogenase). Hence, the reduced ATP production in the mutants must be responsible for the observed phenotype: absence of growth (but viability for several days) under heterotrophic conditions and slower growth under mixotrophic conditions. However, growth studies performed with dum-19 (Fig. 2) show that the addition of acetate to the culture medium significantly improves the growth of the mutant in the light, which indicates that respiration of the exogenous carbon source must be responsible for this improvement. On the other hand, under phototrophic conditions, the growth rate of $d u m-19$ (this study) and other mutants (Dorthu et al. 1992) does not differ markedly from that of the wild type. This indicates that under phototrophic conditions, the ATP produced as a result of mitochondrial respiratory activity does not significantly contribute to the general metabolism of the alga with regard to energy of photosynthetic origin.

The mitochondrial mutations thus far characterized affect only 2 of the 13 genes residing in the $C$. reinhardtii mitochondrial genome. This raises the question of why only the COB and COX1 mitochondrial genes are inactivated by mutation. As discussed earlier (Dorthu et al. 1992; Randolph-Anderson et al. 1993), mutations inactivating ND mitochondrial genes could be lethal, owing to the loss of complex I. The absence of an active complex I would prevent the oxidation of NADH and regeneration of $\mathrm{NAD}^{+}$to supply the Krebs cycle. The essential role of the ND genes for survival is supported by the production of lethal minute colonies in the dum-1 strain, arising from the extension of the $\mathrm{COB}$ deletion into the adjacent ND4 gene (Randolph-Anderson et al. 1993).

Mutations inactivating the mitochondrial rRNA or tRNA genes would prevent protein synthesis in the organelle, including the biosynthesis of complex I. Such mutations would also be lethal for the reasons described above. The essential role of mitochondrial genomic function in Chlamydomonas is also suggested from the results of long-term acriflavine or ethidium bromide treatment. Both dyes cause elimination of the mitochondrial DNA and convert wild-type cells, with almost $100 \%$ efficiency, into lethal minute colony mutants (Gillham et al. 1987). The isolation and characterization of conditional lethal mutations affecting the ND or tRNA or rRNA genes would allow confirmation of this hypothesis.

Acknowledgements We wish to thank Mr. J. Vaassen for technical assistance and Mrs, F. Hayet for manuscript preparation. This research was supported by grants from the Belgian FRFC (2.4520.93), ECC (Human Capital and Mobility), Actions de recherches concertées (ARC 93-98/170) and Fonds spéciaux pour la recherche dans les Universités. M. Colin, M.-P. Dorthu and F. Duby are fellows of IRSIA; C. Remacle is a Senior Research Assistant of the Belgian FNRS.

\section{References}

Beckers M-C, Munaut C, Minet A, Matagne RF (1991) The fate of mitochondrial DNAs of $m t^{+}$and $m t^{-}$origin in gametes and zygotes of Chlamydomonas. Curr Genet 20:239-243

Bennoun P, Delosme M, Kück U (1991) Mitochondrial genetics of Chlamydomonas reinhardtii: resistance mutations marking the cytochrome $b$ gene. Genetics 127:335-343

Bennoun P, Delosme M, Godehardt I, Kück U (1992) New tools for mitochondrial genetics of Chlamydomonas reinhardtii: manganese mutagenesis and cytoduction. Mol Gen Genet 234:147-154

Boer PH, Gray MW (1986) Nucleotide sequence of a protein coding region in Chlamydomonas reinhardtii mitochondrial DNA. Nucleic Acids Res 14: 7506-7507 

Brasseur R (1988) Calculation of the three-dimensional structure of
Saccharomyces cerevisiae cytochrome $b$ inserted in a lipid matrix. J Biol Chem 263:12571-12575

Colleaux L, Michel-Wolwertz M-R, Matagne RF, Dujon B (1990) The apocytochrome $b$ gene of Chlamydomonas smithii contains a mobile intron related to both Saccharomyces and Neurospora introns. Mol Gen Genet 223: 288-296

di Rago J-P, Colson A-M (1988) Molecular basis for resistance to antimycin and diuron, $Q$ cycle inhibitors acting at the $Q_{i}$ site in the mitochondrial ubiquinol-cytochrome $c$ reductase in Saccharomyces cerevisiae. J Biol Chem 263:12564-12570

di Rago J-P, Coppée J-Y, Colson A-M (1989) Molecular basis for resistance to myxothiazol, mucidin (strobilurin A), and stigmatellin. J Biol Chem 264:14543-14548

Dorthu M-P, Remy S, Michel-Wolwertz M-R, Colleaux L, Breyer D, Beckers M-C, Englebert S, Duyckaerts C, Sluse FE, Matagne RF (1992) Biochemical, genetic and molecular characterization of new respiratory-deficient mutants in Chlamydomonas reinhardtii. Plant Mol Biol 18:759-772

Gillham NW, Boynton JE, Harris EH (1987) Specific elimination of mitochondrial DNA from Chlamydomonas by intercalating dyes. Curr Genet 12:41-48

Gorman DS, Levine RP (1965) Cytochrome $f$ and plastocyanin: their sequence in the photosynthetic electron transport chain of Chlamydomonas reinhardtii. Proc Natl Acad Sci USA 54: $1665-1669$

Harris EH (1989) The Chlamydomonas sourcebook. Academic Press, San Diego higher plant respiration. Annu Rev Plant Physiol $24: 445-4$

Ma DP, Yang YW, King YT, Hasnain SE (1990) The mitochon apocytochrome $b$ gene from Chlamydomonas reinhardtii. $\mathrm{P}$ Mol Biol 15:357-359

Matagne RF, Michel-Wolwertz M-R, Munaut C, Duyckaert Sluse F (1989) Induction and characterization of mitochon DNA mutants in Chlamydomonas reinhardtii. J Cell Biol 1221-1226

Michaelis G, Vahrenholz C, Pratje E (1990) Mitochondrial DN Chlamydomonas reinhardtii: the gene for apocytochrome $b$ the complete functional map of the $15.8 \mathrm{~kb}$ DNA. Mol Genet 223:211-216

Randolph-Anderson BL, Boynton JE, Gillham NW, Harris Johnson AM, Dorthu M-P, Matagne RF (1993) ther characterization of the respiratory deficient $d t$ mutation of Chlamydomonas reinhardtii and its use recipient for mitochondrial transformation. Mol Gen G $236: 235-244$

Remacle C, Colin M, Matagne RF (1995) Genetic mappin mitochondrial markers by recombination analysis in Chlam monas reinhardtii. Mol Gen Genet 249:185-190

Sanger F, Nicklen S, Coulson AR (1977) DNA sequencing chain-terminating inhibitors. Proc Natl Acad Sci USA 5463-5467

Vahrenholz C, Riemen G, Pratje E, Dujon B, Michaelis G (1 Mitochondrial DNA of Chlamydomonas reinhardtii: the struc of the ends of the linear $15.8 \mathrm{~kb}$ genome suggests mechanism DNA replication. Curr Genet 24:241-247 